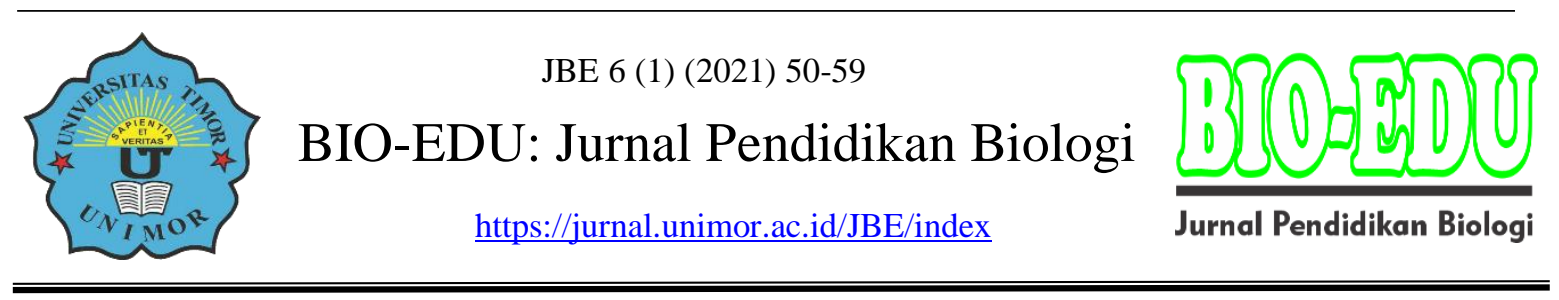

\title{
Urgensi Materi Pembelajaran Tentang Virus Pada Mata Pelajaran IPA di SMP/MTs pada Masa Pandemi COVID-19: Rancangan Indikator Pembelajaran dalam Bentuk Pendidikan Kesehatan di Sekolah
}

\author{
Rhavy Ferdyan ${ }^{1}$, Lufri Lufri ${ }^{1}$, Fitri Arsih ${ }^{{ }^{*}}$ \\ ${ }^{1}$ Universitas Negeri Padang \\ fitribio@fmipa.unp.ac.id
}

DOI: https://doi.org/10.32938/jbe.v6i1.989

\begin{abstract}
Abstrak
Pandemi sangat mempengaruhi semua sudut dan tatanan kehidupan, tidak terkecuali sektor pendidikan. Ilmu Pengetahuan Alam (IPA) merupakan mata pelajaran yang menjembatani pengetahuan siswa tentang masa pandemi ini, dimana pada mata pelajaran ini harus menghadirkan pengetahuan-pengetahuan mengenai virus. Pada kenyataannya, kurikulum merancang materi yang sangat rinci dan membahas tuntas mengenai virus ditemukan di tingkat SMA/MA/SMK, dan sangat minim sekali pada tingkat SD dan SMP/MTs. Melalui artikel ini, akan dijelaskan bagaimana pentingnya materi virus ini diajarkan mulai dari tingkat SMP/MTs yang kondisi siswanya terlebih dahulu penting dan harus mampu menerima pengetahuan mengenai virus daripada tingkat SD. Artikel ini merupakan hasil observasi, studi kepustakaan (literatur review), dan studi dokumentasi yang melahirkan gagasan-gagasan bagaimana pentingnya pengetahuan tentang virus tersebut diketahui sejak dini oleh siswa. Materi virus sangat penting dihadirkan dalam pembelajaran IPA di SMP/MTs dengan pertimbangan cakupan materi yang sangat luas (virologi), materinya yang kontekstual, materinya sebagai rancangan indikator pendidikan kesehatan, dan sebagai rancangan indikator dengan pendidikan tanggap wabah.
\end{abstract}

Kata Kunci: Materi virus, Pembelajaran IPA, Pendidikan Kesehatan, Urgensi materi

\begin{abstract}
The pandemic has greatly affected all corners and structures of life, including the education sector. Natural Sciences is a subject that bridges students' knowledge about this pandemic, where this subject must present knowledge about viruses. In fact, the curriculum designs material that is very detail and thoroughly discusses viruses found at the SMA / MA / SMK level, and very minimal at the SD and SMP / MTs level. Through this article, it will be explained how the importance of this virus material is taught starting from the SMP/MTs level where the condition of students is important first and must be able to receive knowledge about viruses rather than SD level. This article is the result of observations, literature reviews, and documentation studies that give birth to ideas about the importance of knowing the virus from an early age by students. Virus material is very important to be presented in science learning at SMP / MTs with the consideration of a very wide coverage of material (virology), the material is contextual, the material is a design for health education indicators, and as an indicator design with outbreak response education..
\end{abstract}

Keywords: Virus material, Natural Science Learning, Health Education, Urgency of material 


\section{PENDAHULUAN}

Dunia dikejutkan dengan munculnya wabah Virus Corona (COVID-19) pada awal tahun 2020 yang menginfeksi hampir seluruh negara di dunia. Organisasi Kesehatan Dunia atau WHO semenjak Januari 2020 telah menyatakan dunia masuk ke dalam darurat global terkait virus ini, dengan bermunculannya banyak kasus di Tiongkok, Korea Selatan, Jepang dan merambat naik ke Eropa. Fenomena ini merupakan hal yang luar biasa terjadi di bumi pada abad ke 21, yang skalanya mungkin dapat disamakan dengan Perang Dunia II, karena kegiatan-kegiatan skala besar hampir seluruhnya ditunda bahkan dibatalkan. Terhitung mulai tanggal 19 Maret 2020 sebanyak 214.894 orang terinfeksi virus corona, 8.732 orang meninggal dunia dan pasien yang telah sembuh sebanyak 83.313 orang (Aida, 2020).

Pandemi sangat mempengaruhi semua sudut dan tatanan kehidupan, tidak terkecuali sektor pendidikan. Kebijakan-kebijakan yang dikeluarkan untuk membatasi penyebaran COVID-19 berdampak pada berbagai bidang diseluruh dunia khususnya pendidikan di Indonesia. Berbagai kebijakan telah dikeluarkan oleh pemerintah Indonesia untuk mengurangi tingkat penyebaran virus corona dengan memberlakukan social distancing, physical distancing hingga pemberlakuan Pembatasan Sosial Berskala Besar (PSBB) pada beberapa daerah.

Kebijakan tersebut mendesak seluruh elemen pendidikan untuk melaksanakan pembelajaran secara jarak jauh atau dikenal dengan pembelajaran daring (dalam jaringan) berbasis sistem online. Hal ini dilakukan agar semata pembelajaran di kelas tetap berjalan dengan baik, dan transfer ilmu yang dilakukan oleh guru kepada siswa, literasi yang dilakukan siswa, dan semua kegiatan pengembangan kompetensi yang dilakukan oleh siswa tetap berjalan dengan baik. Akan tetapi, kegiatan tersebut belum berjalan efektif, dan konten materi yang disampaikan guru pada dasarnya diterima siswa hanya 50 hingga $60 \%$ saja. Contohnya dapat kita lihat didalam pembelajaran biologi SMA/MA/SMK yang dilakukan di kota Padang, dimana materi yang diterima siswa dalam pembelajaran online hanya 60\% (Ferdyan, Lufri, \& Zulyusri, 2020).

Sistem pembelajaran Biologi juga mendapatkan pengaruh pada masa pandemi. Biologi merupakan mata pelajaran yang menjembatani pengetahuan siswa tentang masa pandemi ini. Pandemi COVID-19 ini kita ketahui disebabkan oleh virus corona jenis baru yang menginfeksi manusia. Karakteristik virus ini adalah kecepatan penyebaran yang tinggi. Maka dari itu siswa harus mengetahui tentang definisi virus, penggolongan virus, pertumbuhan dan perkembangbiakan virus, serta mekanisme infeksi virus harus dikerahui oleh siswa dengan jelas, apalagi di masa pandemi saat ini, dan menginfeksi tentu harus diketahui oleh siswa dengan jelas, apalagi di masa pandemi saat ini.

Sebenarnya materi pembelajaran biologi yang bersifat kontekstual (contextual learning) sangat memudahkan siswa untuk mengenali kehidupan di alam sekitar termasuk tentang virus ini. Contextual teaching and learning (CTL) yaitu, Suatu strategi pembelajaran yang menekankan pada proses keterlibatan siswa secara penuh untuk dapat menemukan materi yang dipelajari dan menghubungkannya dengan situasi kehidupan nyata, sehingga mendorong siswa untuk dapat menerapkannya dalam kehidupan mereka(Sanjaya, 2006). Menghadapi pandemi perlu strategi khusus berbasis pengetahuan, karena dengan mengetahui hal-hal yang berkaitan dengan pandemi, maka langkah-langkah strategis yang dilakukan masyarakat akan lebih efektif dalam menghadapinya, termasuk oleh siswa sendiri di sekolah. Sekolah yang ditutup menjadi 
langkah preventif yang paling efektif untuk mencegah penyebaran wabah pada siswa. Solusi yang diberikan yakni dengan memberlakukan pembelajaran dirumah dengan memanfaatkan berbagai fasilitas penunjang yang mendukung. Siswa sendiri tidak mengetahui mengapa hal demikian dilakukan dan pembelajaran dirumah diketahui hanya melaksanakan kebijakan sekolah atau perintah guru semata. Pengetahuan siswa mengenai virus pada dasarnya harus dilakukan melalui mata pelajaran ilmu alam seperti biologi yang mengupas tuntas mengenai makhluk hidup.

Jika dilihat pada kompetensi dasar IPA yang ada, pengetahuan siswa mengenai virus sangat minim mulai dari tingkat SD/MI dan SMP/MTs, karena materi belum dijelaskan lebih luas. Virus dijelaskan di tingkat SD/MI dan SMP/MTs hanya pada materi klasifikasi makhluk hidup, dan muatan kurikulumnya tidak lebih luas karena banyaknya materi klasifikasi yang harus dijelaskan dan disesuaikan dengan proporsi siswa tingkat SD dan SMP.

Dari observasi yang dilakukan di beberapa SMP/MTs di Kota Padang, materi mengenai virus pada pembelajaran IPA masih minim dijelaskan dan hanya ditemukan pada Bab Klasifikasi makhluk hidup yang menjelaskan sistem lima kingdom pada makhluk hidup. Penjelasannya antara lain mengenai struktur tubuh virus yang sangat kecil, infeksi virus dan informasi mengenai virus dapat menyebabkan penyakit. Hal ini tentunya sangat minim sekali dalam hal informasi yang diperoleh oleh siswa di sekolah terutama pada tingkat SMP/MTs. Sementara saat ini, pandemi sangat menuntut kita lebih berhati-hati dan hidup berdampingan dengan virus yakni COVID-19.

Pada kenyataannya, kurikulum merancang materi yang sangat rinci dan membahas tuntas mengenai virus ditemukan di tingkat SMA/MA/SMK. Siswa baru mengenal virus dengan lebih luas dan memiliki pengetahuan yang baik ditingkat SMA/MA (Ferdyan, Indriati, \& Nerita, 2015). Keadaan terkait pandemi COVID-19 dan struktur kurikulum yang ada membahas mengenai virus ini tentu sebaiknya dilakukan transformasi ke arah pendidikan yang tanggap wabah, lebih tepatnya melalui pendidikan Kesehatan.Pendidikan kesehatan adalah proses perubahan perilaku yang dinamis, di mana perubahan tersebut bukan sekedar proses transfer materi atau teori dari seseorang ke orang lain dan bukan pula seperangkat prosedur, akan tetapi perubahan tersebut terjadi karena adanya kesadaran dari dalam individu, kelompok, atau masyarakat itu sendiri (Wahid \& Chayatin, 2009).

Pandemi COVID-19 menuntut bagaimana mata pelajaran IPA dan biologi khususnya dapat mengkomunikasikan pengetahuan mengenai virus ini kepada siswa ditingkat yang lebih awal sebelum SMA/MA/SMK, sehingga dapat dibentuk model pendidikan yang tanggap dengan wabah. Pengetahuan mengenai virus ini minimal dapat diperoleh siswa di tingkat SMP/MTs melalui mata pelajaran IPA yang kurikulumnya ditransformasikan.

Melalui artikel ini, akan dijelaskan bagaimana pentingnya materi virus ini diajarkan mulai dari tingkat SMP/MTs yang tidak hanya sekedar penjelasan umum mengenai bahaya-bahaya virus dan penyakit-penyakit yang belum diperbaharui pada materinya. Materi virus sangat penting terutama sejak adanya pandemi COVID-19 ini, agar semua siswa dapat memperoleh pengetahuan yang luas mengenai virus.

\section{METODE}

Artikel ini merupakan hasil observasi, studi kepustakaan (literatur review), dan studi dokumentasi yang melahirkan gagasan-gagasan bagaimana pentingnya pengetahuan tentang virus tersebut diketahui sejak dini oleh siswa. Pendekatan yang 
dilakukan adalah analisis kualitatif dan hasilnya dijelaskan secara deskriptif-analisis. Observasi dilakukan pada dokumen kurikulum SMP/MTs yang digunakan di Kota Padang, kurikulum nasional, dan melakukan studi pustaka pada sumber-sumber yang relevan.

\section{HASILDANPEMBAHASAN}

\section{Pentingnya Materi Virus dalam pembelajaran IPA di SMP/MTs}

Materi virus di SMP/MTs dapat ditemukan pada Kompetensi dasar kelas VII SMP/MTs poin 3.2. yaitu mengklasifikasikan makhluk hidup dan benda berdasarkan karakteristik yang diamati. Pada kompetensi dasar ipoin 3.2 virus dibahas bersamaan dengan bakteri dan protista. Hal ini menjadi alasan pertama pentingnya materi virus dikembangkan di SMP/MTs, karena kompetensi dasar yang melandasinya sudah ada sebelumnya. Langkah selanjutnya adalah dengan mengembangkan kurikulum. Kegiatan pengembangan kurikulum terdiri dari penyususunan kurikulum itu sendiri, pelaksanaan di sekolah-sekolah yang disertai dengan penilaian yang intensif, dan penyempurnaanpenyempurnaan yang dilakukan terhadap komponen-komponen tertentu dari kurikulum tersebut atas dasar hasil penilaian (Syarif, 1993).

Alasan kedua bahwa materi virus menjadi sangat mendesak untuk dipelajari di SMP/MTs dan diperlukan pengembangan adalah dapat dibentuknya karakter siswa SMP/MTs untuk mulai mengembangkan standar dan harapan terhadap perilaku diri sendiri yang sesuai dengan dunia sosial (Kemendikbud RI, 2020). Hal inilah yang menjadi pintu masuk dan langkah awal bagi siswa di SMP/MTs untuk memahami lebih mendalam mengenai virus dan mampu mengubah perilaku hidup sehat dikarenakan materi virus di SMP/MTs sekaligus menjadi bahan pendidikan kesehatan di sekolah. Siswa SMP/MTs dianggap lebih cocok dan tepat untuk mulai mendalami materi-materi pembelajaran IPA setelah didapatkan ditingkat SD/MI dan menjembatani pengetahuan ke SMA/MA/SMK.

Alasan ketiga adalah pandemi COVID-19 yang menuntut semua lini masyarakat harus proaktif bahu membahu menangani wabah. Seluruh masyarakat harus cepat dan tanggap mengenai COVID-19 yang merupakan penyakit disebabkan oleh virus corona jenis baru. Oleh karena itu, dengan menghadirkan materi virus di SMP/MTs merupakan strategi memberikan informasi dan pengenalan lebih dini mengenai virus dan bahayanya kepada siswa di sekolah, dimana selama ini kurikulum mengagendakan bahwa pengetahuan mendalam mengenai virus ini diperoleh di kelas X SMA/MA. Kemudian sangat penting sekali untuk memasukkan pendidikan kesehatan ke dalam kurikulum menggunakan pendekatan inovatif untuk meningkatkan perilaku sehat pada siswa di sekolah (Almomani et al., 2021). Hal ini menjadi perhatian penting dalam menghadirkan dan mengembangkan materi pembelajaran IPA tentang virus di SMP/MTs.

\section{Materi virus memiliki cakupan lebih luas dan penting dipelajari di masa pandemi}

Kurikulum memiliki komponen-komponen yang utama antara lain tujuan, isi atau materi, proses atau sistem penyampaian dan media, serta evaluasi. Semua komponen tersebut berhubungan erat satu sama lain. Suatu kurikulum wajib mempunyai kesesuaian atau relevansi (Sukmadinata \& Syaodih, 2001). Kesesuaian yang pertama adalah kesesuaian antara kurikulum dengan tuntutan, kebutuhan, kondisi, dan perkembangan masyarakat. Sedangkan yang kedua adalah kesesuaian antar komponen- 
komponen kurikulum, yaitu isi sesuai dengan tujuan, proses sesuai dengan isi dan tujuan, demikian juga evaluasi sesuai dengan proses, isi dan tujuan kurikulum.

Dari kesesuaian kurikulum seperti yang dijelaskan pada pernyataan diatas, dapat kita lihat bagaimana pentingnya pada materi virus dalam pembelajaran IPA di SMP/MTs saat ini. Kurikulum disesuaikan dengan tuntutan, kebutuhan, kondisi saat ini. Pandemi COVID-19 saat ini menuntut semua lini termasuk sektor pendidikan untuk berperan aktif memberikan informasi kepada masyarakat (siswa) agar memahami bagaimana pandemi hadir dan merusak semua sendi-sendi kehidupan. Maka dari itu, perlu pengembangan materi ajar pada tingkat SMP/MTs mengenai virus ini dengan mengintegrasikan contoh nyata yang terjadi sekarang.

Virologi adalah suatu cabang ilmu biologi yang mempelajari tentang virus dan penyakit-penyakit yang disebabkannya. Virus merupakan parasit atau makhluk hidup yang kehidupannya bergantung pada makhluk hidup lainnya, ukurannya mikroskopik (tidak dapat dilihat oleh mata telanjang) yang menginfeksi sel organisme biologis. Keberadaan virus sendiri sering menjadi kontroversi terutama penggolongannya, sebagai makhluk hidup atau bukan. Keadaan yang mencirikan virus adalah makhluk hidup karena memiliki DNA dan dapat berkembang biak, sedangkan keadaan yang menggambarkan virus disebut benda mati karena tidak memiliki sel dan dapat dikristalkan (Suprobowati \& Kurniati, 2018).

Virologi merupakan cabang ilmu yang luas cakupannya; mulai dari membahas tentang dasar-dasar pengetahuan tentang virus, klasifikasi virus, daur hidupnya, hingga penyakit-penyakit yang disebabkan oleh virus baik yang terjadi pada tumbuhan, hewan, maupun manusia. Kemudian pada virologi juga membahas mengenai patologi, gejala klinis hingga vaksinasi virus. Dari cakupan pembahasan yang ada pada cabang ilmu virologi ini, maka seharusnya materi pembelajaran IPA di SMP/MTs sudah dapat melakukan pengembangan materi virus terkait dengan kebutuhan di masa pandemi COVID-19 ini. Materi yang semulanya hanya berupa subbab yang penjelasannya hanya satu hingga dua paragraf saja mungkin lebih dikembangkan lagi dan ditambah muatannya mengenai materi-materi virologi.

Virus Corona merupakan virus RNA dengan ukuran partikel 60-140 nm (Meng et al., 2020). Hasil mikrograf elektron dari partikel untai negatif 2019-nCoV menunjukkan bahwa morfologi virus umumnya berbentuk bola dengan beberapa pleomorfisme. Diameter virus bervariasi antara 60-140 nm. Partikel virus memiliki protein spike yang cukup khas, yaitu sekitar 9-12 nm dan membuat penampakan virus mirip seperti korona matahari (Zhu et al., 2020). Pengetahuan dan informasi seperti inilah yang perlu ditanamkan pada siswa terutama mengenai pengertian virus corona, keberadaan virus, dan penyakit yang ditimbulkan ada atau tidaknya virus ini, dan apa yang bisa disebabkannya. Pengetahuan mengenai virus corona sangat penting agar siswa di SMP/MTs tidak hanya mengetahui istilah-istilah corona, COVID-19, infeksi dan istilah lainnya tetapi juga mengetahui maknanya.

Bahasan yang diajarkan tidak semata-mata seperti proporsi materi di SMA/MA/SMK, akan tetapi disesuaikan dengan perkembangan zaman, kondisi, tuntutan yang dibutuhkan saat ini. Agar pengetahuan siswa secara kognitif bertambah, dan praktik yang dilakukan siswa dalam pencegahan infeksi virus di masa pandemi menjadi nilai dalam psikomotriknya.

\section{Materi virus adalah materi yang kontekstual untuk dipelajari di masa pandemi}

Contextual Teaching Learning (CTL) adalah konsep belajar yang membantu guru menghubungkan antara materi yang diajarkan dalam poembelajaran dengan situasi 
dunia nyata dan memotivasi siswa membuat hubungan antara pengetahuan yang dimilikinya dengan perencanaan dalam kehidupan mereka sehari- hari (Mulyasa, 2010). The Washington State Consortium for Contextual Teaching and Learning mengartikan pembelajaran kontekstual adalah pengajaran yang memungkinkan siswa memperkuat, memperluas, dan menerapkan pengetahuan dan keterampilan akademisnya dalam berbagai latar sekolah dan diluar sekolah untuk memecahkan seluruh persoalan yang ada dalam dunia yang nyata (Komalasari, 2010).

Pada masa pandemi ini, materi virus adalah materi yang sangat kontekstual dan menjadi alasan perlunya dihadirkan di tingkat SMP/MTs yang pembahasannya belum mendalam mengenai virus. Saat ini, guru sangat mudah memberikan analogi dan memotivasi siswa untuk belajar didalam kehidupan nyata mereka untuk mengenai apa yang dikatakan dengan virus melalui informasi-informasi yang mereka peroleh dari COVID-19.

Melalui konsep Contextual Teaching Learning (CTL) dan posisi materi virus dalam pembelajaran IPA di SMP/MTs sebagai materi yang kontekstual, ada beberapa hal yang terkandung didalamnya. Pertama, CTL menekankan kepada perjalanan dan keterlibatan siswa untuk menemukan materi, artinya proses belajar diorientasikan pada proses pengalaman secara langsung (Kunandar, 2017). Hal ini dapat terwujud dengan terlebih dahulu menghadirkan materi virus dalam pembelajaran. Setelah itu materi yang dirancang melalui pengembangan kurikulum, harus menyuguhkan dan memberikan panduan kepada siswa untuk mencari pengetahuan sebanyak-banyaknya secara mandiri Pembelajaran di lingkungan sekitar saat ini dapat dengan mudah dilakukan, dimana informasi-informasi tentang virus khususnya COVID-19 sangat banyak; mulai dari infografis, pamflet, siaran televisi, radio, dan media sosial. Siswa juga dapat dituntut untuk mengamati lingkungan sekitar terhadap warga masyarakat yang terinfeksi virus. Kedua, CTL memotivasi siswa agar dapat melihat hubungan antara materi yang dipelajari dengan situasi kehidupan nyata, artinya siswa dituntut untuk dapat menangkap hubungan antara belajar di sekolah dengan kehidupan nyata. Pentingnya hal ini dilakukan sebab dengan mampu menghubungkan materi dengan kehidupan nyata, materi akan bermakna bukan saja bagi siswa secara fungsional, akan tetapi materi yang dipelajarinya tersebut akan tertanam erat dalam memori siswa, sehingga tidak mudah dilupakan (Kunandar, 2017). Dengan adanya materi virus didalam kurikulum pembelajaran IPA di SMP/MTs, dapat dengan mudah dikaitkan oleh siswa kedalam kehidupan nyata sehingga materi sangat mudah diingat oleh siswa. Pandemi saat ini sangat kontekstual dan mudah dikaitkan oleh siswa dengan materi mengenai virus. Prediksi yang dapat dilakukan, siswa SMP akan mudah mengenali virus melalui pembelajaran IPA saat pandemi ini maupun pasca pandemi nantinya. Kehidupan saat ini sudah dikenal dengan era new normal, dimana pengetahuan mesti ditingkatkan mengenai virus. Ketiga adalah CTL mendorong siswa untuk dapat menerapkannya dalam kehidupan, artinya CTL bukan hanya mengharapkan siswa dapat memahami materi yang dipelajarinya, akan tetapi bagaimana materi pelajaran itu dapat mewarnai perilakunya dalam kehidupan sehari- hari. Jika dikaitkan dengan urgansi materi virus dalam IPA dan pandemi COVID-19, poin ini dapat dijelaskan bahwa penerapan yang penting dilakukan oleh siswa adalah penerapan protokol kesehatan yang ketat setelah mengenali virus dari pembelajaran di sekolah. Salah satunya dengan tidak lupa melakukan perilaku 3M (Memakai masker, Menjaga jarak, dan Mencuci tangan). Salah satu teori pembelajaran CTL adalah socialization; teori ini beranggapan bahwa belajar merupakan proses sosial yang menentukan terhadap tujuan belajar. Oleh karena itu, 
faktor sosial dan budaya merupakan bagian dari sistem pembelajaran. Perilaku 3M yang dilakukan siswa, sudah menuntut siswa untuk memikirkan dampaknya terhadap orang lain jika tidak melakukan sekaligus sebagai sistem sosial untuk mencapai tujuan pembelajaran. Dengan mempelajari materi virus, siswa mengetahui bagaimana penularan virus dari manusia ke manusia seperti virus corona yang menyebabkan COVID-19. Materi virus dalam pembelajaran IPA diharapkan tidak hanya dipahami oleh siswa dan stagnan pada teori-teori saja, akan tetapi siswa harus mengalami perubahan perilaku setelah mempelajarinya dan mengaitkan dengan kondisi nyata saat ini. Karena pada dasarnya upaya yang dapat dilakukan oleh sektor pendidikan dalam menanggulangi wabah COVID-19 ini adalah dengan melakukan edukasi semaksimal mungkin melalui siswa di sekolah.

\section{Materi virus dalam pembelajaran IPA SMP/MTs sebagai rancangan pendidikan Kesehatan}

Pendidikan kesehatan merupakan suatu penerapan konsep pendidikan yang dituangkan di dalam bidang kasehatan. Dilihat dari segi pendidikan, pendidikan kesehatan adalah suatu pedagogik praktis atau praktik pendidikan (Bensley, 2009). Pendidikan kesehatan bukan hanya berupa pembelajaran di kelas, tetapi merupakan seluruh pengalaman dimanapun dan kapanpun sepanjang dapat mempengaruhi pengetahuan sikap dan kebiasaan sasaran pendidikan.

Materi virus pada pembelajaran juga seharusnya tidak hanya menjelaskan konsepkonsep virus dan klasifikasinya saja, melainkan juga membahas bagaimana virus tersebut menyebabkan dan menularkan penyakit kepada manusia dan hal apa yang harus dilakukan oleh manusia untuk menghindari infeksi virus. Pada indikator-indikatornya juga sebaiknya ditambahkan mengenai upaya preventif terhadap penyakit yang disebabkan oleh virus. Pada masa pandemi seperti saat ini, topik-topik yang relevan mengenai virus dan COVID-19 secara spesifiknya sangat dibutuhkan. Sesuai dengan penjelasan konsep pendidikan Kesehatan, maka perlu dikaitkan dengan materi virus pada pembelajaran yang bersifat kontekstual dengan pengalaman belajar yang bisa diperoleh oleh siswa sehari-hari, dan materi virus dalam pembelajaran IPA menjadi landasan agar pendidikan kesehatan tersebut terlaksana.

Pendidikan kesehatan dapat dievaluasi dan disebut berhasil jika sasaran pendidikan (individu, keluarga, kelompok dan masyarakat) mampu mengubah sikap dan tingkah lakunya relevan dengan tujuan pendidikan yang telah ditetapkan (Setyabudi, 2017). Materi virus dapat menunjang hal tersebut. Melalui materi virus yang dipelajari siswa di tingkat SMP/MTs, dapat membentuk karkter siswa yang paham akan potensipotensi yang disebabkan oleh virus yakninya penyakit yang pada dasarnya menular dan dapat menjadi wabah seperti COVID-19.

Upaya preventif terhadap penyakit yang berasal dari menjadi langkah yang konsep-konsepnya harus dikuasai oleh siswa di SMP/MTs. Saat ini, istilah preventif atau pencegahan baru mulai dan dituangkan dalam kurikulum SMA/MA, dan belum muncul pada kurikulum IPA di SMP/MTs. Tindakan preventif dilakukan manusia, baik itu secara pribadi atau juga berkelompok untuk dapat melindungi diri mereka dari hal buruk yang mungkin dapat terjadi. Mencegah penyakit yang disebabkan oleh virus menjadi hal yang utama, pengetahuan, dan kemampuan tersendiri yang harus dimiliki oleh siswa di tingkat SMP/MTs. Maka dari itu, pengetahuan tersebut telah diterima siswa sejak dini di sekolah melalui materi virus. Pada titik inilah materi virus di SMP/MTs sangat penting untuk dikembangkan. 
Indikator yang dapat dibuat dalam merancang pendidikan Kesehatan dari materi pembelajaran mengenai virus di SMP/MTs dapat dilihat pada tabel 1 berikut:

Tabel 1. Indikator Pendidikan Kesehatan Melalui pembelajaran IPA di SMP/MTs

\begin{tabular}{|c|c|c|c|}
\hline No & Kompetensi & Indikator & Urgensi \\
\hline \multirow{3}{*}{1} & \multirow{3}{*}{$\begin{array}{l}\text { Materi virus sebagai } \\
\text { bahan pembelajaran } \\
\text { dan objek Pendidikan } \\
\text { kesehatan melalui } \\
\text { pembelajaran IPA di } \\
\text { sekolah di masa } \\
\text { pandemi. }\end{array}$} & $\begin{array}{l}\text { 1.1. Mengenal proses infeksi } \\
\text { oleh virus (daur hidup) } \\
\text { beserta contoh-contohnya } \\
\text { (diutamakan COVID-19) }\end{array}$ & $\begin{array}{l}\text { Perlu dikembangkan } \\
\text { dari materi } \\
\text { Klasifikasi Makhluk } \\
\text { Hidup di SMP/MTs }\end{array}$ \\
\hline & & $\begin{array}{l}\text { 1.2.Mengenal gejala-gejala } \\
\text { penyakit yang disebabkan } \\
\text { oleh virus (diutamakan } \\
\text { COVID-19) }\end{array}$ & $\begin{array}{lr}\text { Perlu dikembangkan } \\
\text { dari materi } \\
\text { Klasifikasi Makhluk } \\
\text { Hidup di SMP/MTs }\end{array}$ \\
\hline & & $\begin{array}{l}\text { 1.3.Mampu melakukan upaya } \\
\text { preventif terhadap } \\
\text { penyakit yang disebabkan } \\
\text { oleh virus (diutamakan } \\
\text { COVID-19) }\end{array}$ & $\begin{array}{l}\text { Perlu dikembangkan } \\
\text { dari materi } \\
\text { Klasifikasi Makhluk } \\
\text { Hidup di SMP/MTs }\end{array}$ \\
\hline
\end{tabular}

Dari tabel diatas dapat dilihat ada tiga indikator yang dapat dikembangkan sebagai bahan pendidikan Kesehatan dari materi virus di SMP/MTs. Pertama adalah mengenali proses infeksi virus, mengenal gejala-gejala penyakit yang disebabkan virus, dan mampu melakukan upaya preventif terhadap penyakit yang disebabkan virus.

Indikator yang dirancang berdasarkan materi virus pada dasarnya merupakan langkah untuk mencapai tujuan pendidikan kesehatan yang menjadi domain sebenarnya. Tujuan pendidikan kesehatan adalah peserta didik memperoleh pengetahuan dan pemahaman tentang seberapa penting tercapainya perilaku kesehatan sehingga dapat meningkatkan derajat kesehatan fisik, mental dan sosial, sehingga produktif secara ekonomi maupun sosial (Joesafira, 2012). Khususnya indikator kamampuan siswa untuk melakukan upaya preventif merupakan muara tercapainya tujuan pendidikan kesehatan salah satunya melalui materi virus dalam pembelajaran IPA.

Sebelumnya, dunia bergantung pada pendidikan kesehatan yang efektif untuk memfasilitasi respon perilaku yang akan memperlambat penyebaran pandemi COVID19. Pencegahan, mitigasi risiko, dan pengendalian COVID-19 merupakan prioritas kesehatan masyarakat yang sangat tinggi (Stellefson, et al, 2021). Dari hal ini, sangat jelas sekali terlihat bahwa materi virus pada pembelajaran IPA sangat urgen dikembangkan di tingkat SMP/MTs, dengan pertimbangan perolehan pengetahuan sejak dini oleh siswa dan cara yang tepat dalam bahu-membahu untuk mencegah penyebaran virus corona dalam masa pandemi ini. Dengan pengetahuan yang didapatkannya mengenai virus khususnya informasi dan pengetahuan tentang COVID-19 ini, diharapkan siswa mampu mengubah perilaku dalam upaya pencegahan terhadap COVID-19 sehingga tujuan pendidikan kesehatan yang sebelumnya dirumuskan tersebut tercapai. 


\section{KESIMPULAN DAN SARAN}

\section{Kesimpulan}

Keseluruhan artikel ini sudah menjelaskan seberapa pentingnya materi pembelajaran IPA tentang virus pada tingkat SMP/MTs dihadirkan dan dikembangkan pada kurikulum seiring dengan kondisi wabah COVID-19 yang menuntut perubahan saat ini. Materi virus dalam pembelajaran IPA di SMP/MTs sangat penting untuk dikembangkan karena materi tersebut memiliki cakupan sangat luas yang berbasis pada salah satu cabang biologi yakni ilmu virologi. Kemudian materi virus ini sangat kontekstual dan dapat dipelajari oleh siswa saat sekarang ini melalui pengamatan lingkungan sektiar khususnya mengenai COVID-19. Materi virus juga dapat menjadi rancangan indikator dalam mengembangkan pendidikan kesehatan bagi siswa di sekolah sesuai dengan kebutuhan, tuntutan, dan kondisi pandemi saat ini yang meminta pengetahuan yang mendalam untuk memahami untuk memahami virus sebagai langkah dalam mengantisipasi wabah.

\section{Saran}

Artikel ini memberi saran untuk menghadirkan dan mengembangkan materi tentang virus dalam pembelajaran IPA di tingkat SMP/MTs sebagai bentuk antisipasi dan perolehan pengetahuan sejak dini oleh siswa mengenai virus khususnya di masa pandemi seperti sekarang ini. Hal ini dapat dilakukan dengan pengembangan kurikulum dengan mengembangkan kompetensi dasar pembelajaran IPA terkait materi virus dan menyesuaikan dengan kebutuhan dan kondisi pandemi. Kemudian transformasi tersebut akan memudahkan dalam merancang indikator pendidikan kesehatan melalui pembelajaran IPA di sekolah.

\section{DAFTAR RUJUKAN}

Aida, N. R. (2020). Update Virus Corona di Dunia: 214.894 Orang Terinfeksi, 83.313 Sembuh, 8.732 Meninggal Dunia. Retrieved February 8, 2021, from https://www.kompas.com/tren/read/2020/03/19/081633265/update-virus-coronadi-dunia-214894-orangterinfeksi-83313-sembuh-8732

Almomani, M. H., Rababa, M., Alzoubi, F., Alnuaimi, K., Alnatour, A., \& Ali, R. A. (2021). Effects of a health education intervention on knowledge and attitudes towards chronic non-communicable diseases among undergraduate students in Jordan. Nursing Open, 8(1), 333-342.

Bensley, R. J., \& Brookins-Fisher, J. (2009). Metode Pendidikan Kesehatan Masyarakat. EGC.

Ferdyan, R., Indriati, G., \& Nerita, S. (2015). Tinjauan Upaya Preventif Siswa Terhadap Penyakit yang Berasal dari Mikroba Setelah Mempelajari Materi Virus dan Bakteri di SMAN 16 Padang. STKIP PGRI Sumatera Barat.

Ferdyan, R., Lufri, L., \& Zulyusri, Z. (2020). Content Analysis and Implementation of Biology Online Learning Materials in SMA/MA/SMK During The COVID-19 Pandemic. Journal of Biology Education, 9(3), 41-348.

Joesafira, J. (2012). Pengaruh Tingkat Pendidikan Orang Tua terhadap Prestasi Belajar Siswa Kelas III SDN 1 Karang Anyar. Universitas Negeri Yogyakarta.

Kemendikbud RI. (2020). Karakteristik Siswa Sekolah Menengah Pertama (SMP). 
Retrieved February 8, 2021, from http://silnriyadh.kemdikbud.go.id/smp/2020/04/16/karakteristik-siswa-sekolah-menengahpertama-smp/

Komalasari, K. (2010). Pembelajaran Kontekstual Konsep dan Aplikasi. Bandung: PT Refika Aditama.

Kunandar, K. (2017). Guru Profesional, Implementasi Kurikulum. Jakarta: Rajawali Press.

Meng, H., Xiong, R., He, R., Lin, W., Hao, B., Zhang, L., \& Lu, Z. (2020). CT Imaging and Clinical Course of Asymptomatic Cases with Covid-19 Pneumonia at Admission in Wuhan, China. Journal of Infection, 81(1), 33-39.

Mulyasa, E. (2010). Kurikulum Berbasis Kompetensi: Konsep, Karakteristik, dan Implementasi. Jakarta: Remaja Rosdakarya.

Sanjaya, W. (2006). Strategi pembelajaran berorientasi standar proses pendidikan. Jakarta: Kencana.

Setyabudi, R. G. (2017). Analisis Strategi Promosi Kesehatan Dalam Rangka Meningkatkan Kesadaran Hidup Sehat Oleh Rumah Sakit Jiwa Daerah Dr. RM. Soedjarwadi Provinsi Jawa Tengah. Universitas Islam Indonesia.

Stellefson, M., Paige, S., Wang, M. Q., \& Chaney, B. H. (2021). Competency-based recommendations for health education specialists to prevent the spread of COVID-19 among adults with COPD. American Journal of Health Education, 52(1), 18-22.

Sukmadinata, S., \& Syaodih, N. (2001). Pengembangan Kurikulum: Teori dan Praktek. Bandung: Rosda Karya.

Suprobowati, O. D., \& Kurniati, I. (2018). Bahan Ajar Teknik Laboratorium Medik (TLM): Virologi. Jakarta: PPSDMK Kemenkes RI.

Syarif, A. (1993). Pengembangan Kurikulum. Surabaya: Bina Ilmu.

Wahid, I., \& Chayatin, N. (2009). Ilmu Kesehatan Masyarakat: Teori dan Aplikasi. Jakarta: Salemba Medika.

Zhu, N., Zhang, D., Wang, W., Li, X., Yang, B., \& Song, J. (2020). A Novel Coronavirus from Patients with Pneumonia in China, 2019. The New England Journal of Medicine, 382(8), 727-733. 